\title{
Corporate governance under conditions of crisis
}

\author{
Aybika Beksultanova ${ }^{1, *}$, Andrey Seleznev ${ }^{2}$, Saida Shardan $^{3}$ \\ ${ }^{1}$ Chechen State University named after A. A. Kadyrov, 364024, Sheripova A. st. 32, Grozny, Russia \\ ${ }^{2}$ Ulyanovsk Civil Aviation Institute, 432071, Mozhaiskogo st. 8/8, Ulyanovsk, Russia \\ ${ }^{3}$ North Caucasian State Academy, 369001, Krasnoarmeyskaya st. 85 A, Cherkessk, Russia
}

\begin{abstract}
The study investigates the consequences of the COVID-19 virus pandemic on the activities of the board of directors, corporate governance practices and the strategic context of companies' activities. The purpose of the study - assess the readiness (after the fact) of the boards of directors to act in a crisis situation, the specifics of the practice of the boards of directors in the new realities, expectations of the long-term impact of the COVID-19 pandemic on corporate governance practices and the strategic context of the company's activities. The article outlines some issues that are worth considering and that may be useful to the company's management in terms of crisis management. A set of proposals has been formed to reduce the negative effects associated with the consequences of the pandemic for corporate governance, as well as ideas and practical proposals that can help companies reduce the costs of going through the current crisis.
\end{abstract}

\section{Introduction}

At the beginning of the second decade of the 21 st century, the world economy found itself under the simultaneous blow of two crises: the coronavirus pandemic and the collapse of prices for hydrocarbons, primarily for crude oil [1]. The imposition of a double external shock - the coronavirus pandemic and the global economic recession on the problems and contradictions that have accumulated in the world makes it necessary to evaluate with particular care the ideas and solutions of the past that have justified and unjustified themselves [2].

The slow-burning or creeping crisis has a long incubation time and may keep simmering long after the "hot phase" of the crisis is over. It does not have a clear beginning or ending. It can remain undefined for a lofng time; it can change meaning during its lifespan. Tensions between Iran and the United States, refugee flows, the changing climate, wildfires in Australia and, of course, the COVID-19 pandemic - these are all slow-burning crises: they have a seemingly permanent, epochal character, generating regular outbursts without reaching closure [11].

The COVID-19 virus pandemic has serious consequences in all countries of the world and it has a significant impact on the activities of companies and their governing bodies. All participants in management processes are looking for answers to the questions posed by the

\footnotetext{
* Corresponding author: adamovaaybika@mail.ru
} 
pandemic. Regulators are thinking about what changes need to be made and for how long in relation to the rules governing the conduct of important corporate actions of companies, the disclosure of information about their activities based on the results of the completed period and in relation to the current period.

Corporate governance bodies are looking for ways to organize effective work in the current conditions, answers to emerging new challenges associated with both abrupt changes in the business environment and in labor and management processes within companies.

Financial infrastructure institutions (exchanges, registrars, depositories, auditors, etc.) are looking for ways to increase the return on their activities for companies. Experts are looking for ways to help companies solve numerous emerging problems that have no precedent in the past [3].

An effective board of directors is a prerequisite for successful corporate governance and stable business development of a company. As a result, the performance indicators of the company depend on the content of the tasks that the board of directors sets before the management, on what questions it asks during meetings and how carefully it checks the information [4].

The term "corporate governance" can be found today in various branches of economics. Due to the breadth of application of the concept, it does not have a single definition. For example, the International Finance Corporation (IFC) considers corporate governance as "structures and processes of company management and control over them." Experts from the Federal Service for Financial Markets add to this definition a mandatory link between management and economic performance of business entities, noting that capital raising and building up should be part of corporate governance.

The most complete can be called the definition formulated by the Organization for Economic Cooperation and Development (OECD): corporate governance is a system of management and control over a company that has a mandatory structure. The system should have a distribution of rights and responsibilities between the participants of corporate relations (management, shareholders, etc.) and clear rules for decision-making. Within the framework of corporate governance, the company's tasks, funds for the implementation of these tasks and control are determined.

But, regardless of the approach, corporate governance of the enterprise contains common elements:

- Formed system of company management and control over its activities. The meeting of shareholders develops key decisions that are subsequently implemented by senior managers. - The structure that determines the distribution of rights and responsibilities between the participants in corporate governance.

- Rules for making decisions, a framework for achieving goals and monitoring the results of the company.

Thus, corporate governance formulates uniform "rules of the game", stabilizes the management process, promotes the growth of trust in the company from potential investors, government agencies and other stakeholders [5].

\section{Methods and types of the Earth's remote sensing}

The study contains survey findings of 30 representatives of the board of directors of Russian companies representing different sectors of the economy from all over Russia in order to assess the impact of the COVID-19 pandemic on the activities of the board of directors, corporate governance practices and the strategic context of companies. The methods of the research performed contain theoretical and empirical parts, survey methods, descriptions and are supported by graphical methods of illustrating data. 


\section{Analysis of the main ERS data sources for the DEM development}

The study, conducted to assess the impact of the COVID-19 pandemic on the board of directors, corporate governance practices and the strategic context of companies, was attended by board members of 30 Russian companies representing various sectors of the economy. The survey was conducted in May and June 2020.

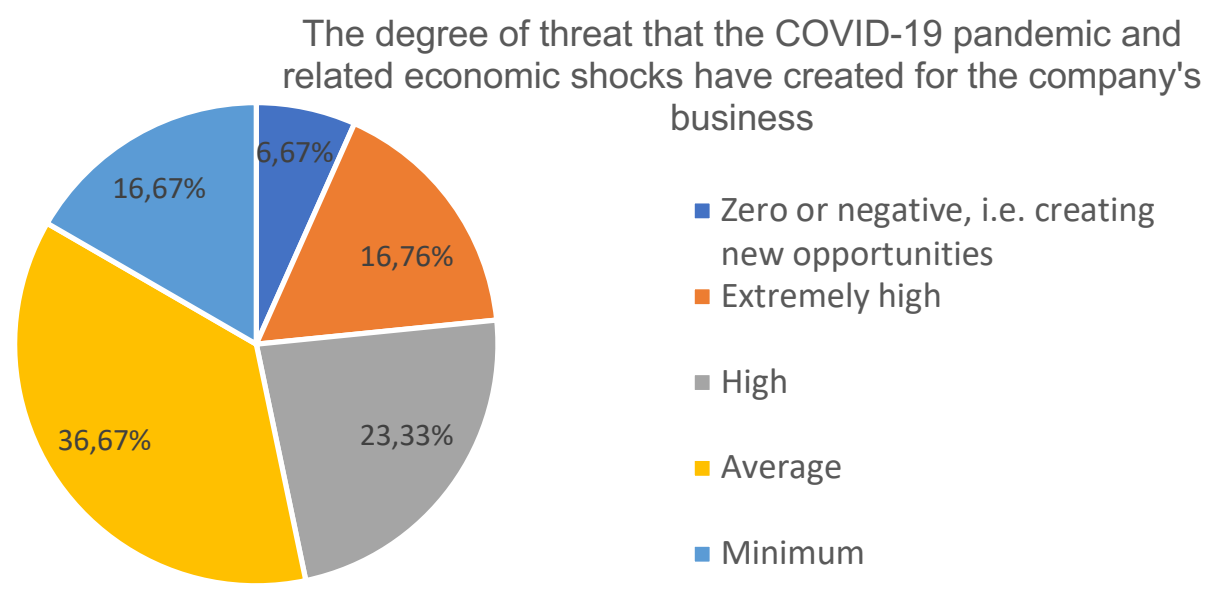

Fig. 1. The degree of impact of the COVID-19 pandemic on the activities of the board's directors.

\section{Has the role of the board of directors in managing the company changed in a pandemic situation?}

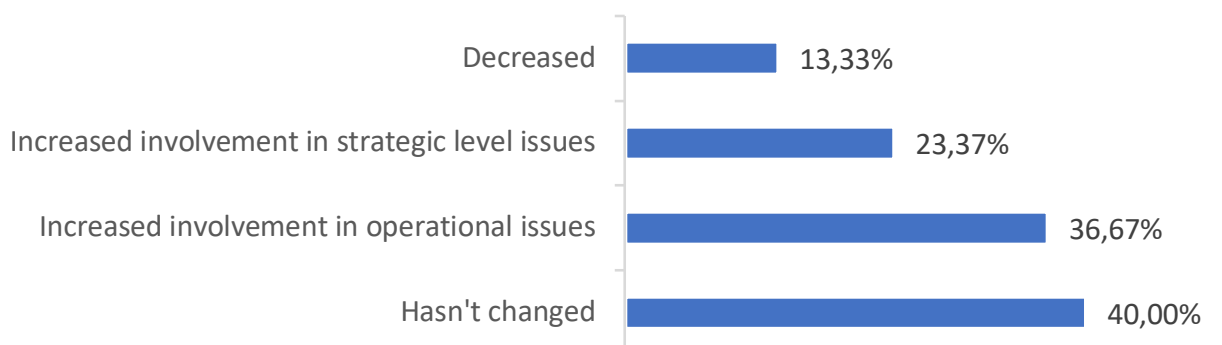

Fig. 2. Impact assessment of the COVID-19 pandemic on the activities of the board's directors 


\section{What disadvantages in the composition and practice of the board of directors did the crisis reveal?}

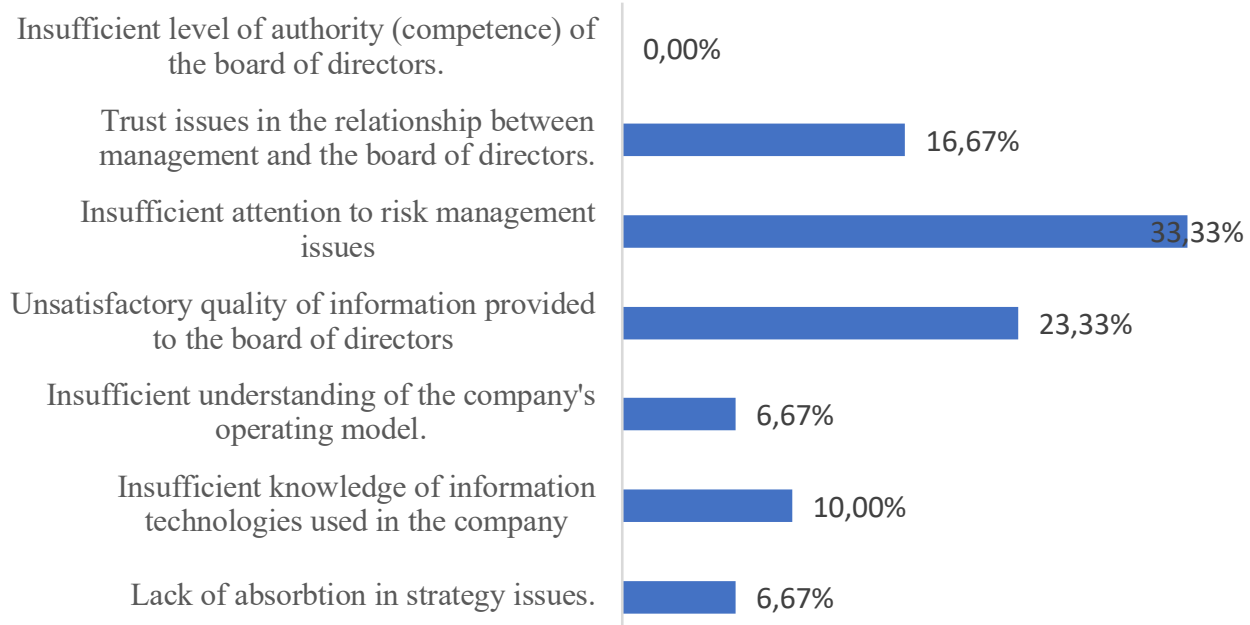

Fig. 3. Impact assessment of the COVID-19 pandemic on the activities of the board of directors.

According to the study, boards of directors considered the challenges of the pandemic in a timely manner - it was stated by $90 \%$ of those surveyed. $37 \%$ did so in February, and another $37 \%$ in the first half of March.

Despite the fact that, in the opinion of the respondents, the boards of directors generally reacted effectively on the onset of the COVID-19 pandemic, the study still managed to identify some problems.

$33 \%$ of respondents noted that boards of directors did not pay enough attention to business risks, $23 \%$ of respondents complained about the low quality of information provided to boards of directors for consideration, $17 \%$ said they lacked trust in relations with management, and another $17 \%$ admitted that board members lack expertise in specific functional areas.

Although the pandemic has impacted on the practice of the boards of directors, it will not lead to significant changes in corporate governance in the future. Boards' involvement in operational and strategic issues has increased - this was stated by 37 and $23 \%$ of respondents, respectively. Also, key shareholders have become more interested in operational and strategic issues - 17 and $27 \%$ of respondents, respectively".

In the future, the boards of directors will more carefully analyze the risks of the business $(83 \%)$ and the company's activities as a whole. $90 \%$ of respondents do not expect changes in the practice of forming the composition of the board, $93 \%$ - in the powers of the board, $83 \%$ - in the role of key shareholders in management.

According to $40 \%$ of respondents, the pandemic creates a high or medium $37 \%$ of respondents) degree of threat to business and, therefore, will change the context of the company's activities.

$40 \%$ of respondents expect changes in the nature of demand, $42 \%$ - an increase in the role of the state in the industry.

The pandemic will significantly affect the business of companies in both the strategic and technological aspects of their activities. 14\% of companies will change their profile of activity, and another $14 \%$ of those surveyed admit this possibility. $18 \%$ of respondents expect 
a shift in focus of activities to the national market, and $72 \%$ - a long-term change in the practice of using information technology. $61 \%$ of respondents expect to change the practice of using office space [6,7].

First of all, the COVID-19 pandemic is a global health crisis. At the same time, its impact on the global economy is growing exponentially and has both short-term and long-term consequences for business. Enterprises need to confront this crisis effectively. Each level of the corporate structure plays its role in responding to the crisis by ensuring the implementation of best practices.

Below are some issues, that are worth considering and which may be useful to the company's management in terms of crisis management. Ideas and practical proposals have already emerged that can help companies reduce the costs of going through the current crisis, namely:

1) By introducing digital technologies

Due to the crisis caused by the COVID-19 pandemic, digital initiatives will become the main strategic business priority for boards of directors in the next two years. In second place is interaction with clients and distant personnel.

Digital technologies play a transformative role in achieving strategic business priorities.

According to foreign experts, it is expected that analytics and artificial intelligence will be most in demand in a pandemic, as company management relies on them to make more reasoned decisions in the new reality and distant work of teams[8].

2) Commitment to environmental practices, social responsibility and corporate governance Demonstrate leadership and maintain a proper corporate culture. In particular, the health and safety of employees are of paramount importance, and therefore it is necessary to take into account the impact of COVID-19 on employees and business.

- Review/revise your Business Continuity Plan (BCP), and update it (if necessary) to determine if it provides for the current scenario. If not, it is necessary to consider the possibility of an immediate update of the BCP.

- Use the compliance function to monitor observance of the policies and procedures of the BCP?. Make sure that the employees of this function are aware of the possibility of submitting issues for consideration in real time, with direct access to the Board of Directors.

3) The Board of Directors

To supervise the anti-crisis management. It is necessary to hold extraordinary and/or special meetings of the Board of Directors. It is necessary to use these meetings to set the "tone from above" regarding the urgency of interaction with the crisis to give a clear signal about the presence of strong leadership and supervision.

Create a special COVID-19 counteraction committee or an anti-crisis committee, or a risk management committee that will oversee the impact of the crisis on your business.

Conduct an open discussion on whether the Board of Directors has the knowledge and skills necessary to oversee the implementation of the BCP, as well as oversee the management of the company during a crisis. If there is no open discussion, then in the short term it is necessary to strengthen the Board of Directors through the involvement of external experts, and in the long term - to revise the composition of the Board of Directors.

The company must have an emergency succession plan ready to be implemented. When a crisis begins, effective corporate governance allows companies to plan effectively anticrisis response measures, distribute clearly defined functions and responsibilities, as well as implement an effective communication strategy. Such actions help companies to recover quickly and minimize damage to their business.

4) Management

- Create a crisis management group of top managers in the company to develop a comprehensive plan to overcome the consequences of the crisis under various possible 
scenarios. The plan should correspond to the intensity and duration of the crisis, the potential impact on liquidity, financing, key business lines and supply chains.

Create channels of periodic communication between the crisis management group and the anti-crisis committee of the Board of Directors.

Identify who is of paramount importance to the company during this crisis and what critical "crisis management skills" may be needed, potentially forming teams working from different locations.

Consider the expediency of including liquidity in the focus of the crisis management team.

5) Control environment

-Internal control: adequacy of BCP policies and procedures; IT control mechanisms related to distant work; workplace safety; food safety, etc. Keep in sight problematic IT issues. In times of crisis, these weaknesses can get worse.

- Compliance: adequacy of compliance with the relevant control measures, including, but not limited to, BCP, IT, security, etc.

- Internal audit: the ability to implement alternative procedures to continue the audit and reporting work plan, assess the adequacy of the $\mathrm{BCP}$, advise on deficiencies in the relevant control mechanisms and measures to eliminate them.

- Risk management: risk assessment and measures to mitigate relevant existing risks, as well as their long-term consequences.

If these aspects have not been recently checked, or there is no certainty that such a check has been carried out, it should be performed. If these aspects have been checked recently, it is necessary to continue to monitor the implementation of appropriate measures in combination with regular reporting and necessary corrective actions.

6) Disclosure of information and transparency

- It is necessary to maintain direct and regular communication with investors and all important stakeholder groups about how COVID-19 affects the business. Stakeholders include employees, customers, suppliers, local communities and local governments.

- Publish information on measures and practices related to COVID-19 on its website in the case of a diversified shareholder and stakeholder base.

- Consider disclosure requirements regarding material changes that may affect profits and future prospects.

- Develop and implement an internal communication company by the executive body, which provides that employees stay at home in case of illness or do not come to work until certain time. Constant communication and openness in relations with investors and stakeholders can create an atmosphere of trust and a good reputation for the company.

7) Managing stakeholder engagement

- Communicate key information about the company's anti-crisis measures to main stakeholders, in particular employees, customers, suppliers, local communities, and health system officials.

- Implement a confidential reporting mechanism that allows employees, suppliers and customers to communicate their concerns about preventing the spread of the virus [9].

\section{Conclusions}

A global survey of the board of directors during the COVID-19 crisis shows that many directors are less pessimistic. In fact, half of the respondents have a more positive outlook, and about a third have more negative expectations. This change in outlook naturally depends on the industry: CFOs in semiconductors, retail, software and services are much more optimistic about revenues and profits from the pandemic, while CFOs in industrial goods (such as the automotive) still see relatively little reason for optimism. 
In general, most CFOs believe that the economic consequences of the crisis remain serious. Regarding the recovery, CFOs in European and US companies tend to believe that it will be in a U-shape with a sustained recession before the economy returns to pre-crisis levels. Asian CFOs are leaning towards an even more pessimistic L- or W-shaped scenario. However, regardless of their views, CFOs around the world continue to take decisive measures to support their business in times of crisis, putting costs, cash and productivity at the forefront. In addition, more than $80 \%$ of surveyed CFOs also consider transformational changes, for example, in their organization, in digital technologies or innovations, as a strategic opportunity.

The economic consequences of the coronavirus require corporate leaders to act in several directions at once: meeting the needs of employees, ensuring business stability, continuous analysis of the changing business and social context, and preparing the company for successful work in the new reality [10].

In general, according to the results of the study, Russian business expects to reach precrisis development indicators no earlier than by the end of December 2020. Nevertheless, according to the most optimistic forecasts of market players, the Russian economy will not begin a full recovery in 2020 .

\section{References}

1. A. Dynkin, E. Telegina, Pandemic shock and the world after the crisis, World Economy and International Relations, 8, 5-16 (2020). Access mode: https://doi.org/10.20542/0131-2227-2020-64-8-5-16

2. L. Fituni, I. Abramova, Developing countries in the political economy of the postcoronavirus world, World Economy and International Relations, 9, 5-14 (2020). Access mode: https://doi.org/10.20542/0131-2227-2020-64-9-5-14/

3. Corporate governance during the pandemic (2020). Access mode: https://amr.ru/committees/korpu/news/korporativnoe-upravlenie-v-period-pandemii-/

4. Board of Directors - legal aspects of activity. Access mode: https://lfacademy.ru/boardof-directors

5. Corporate governance system (2020). Access mode: https://blog.iteam.ru/sistemakorporativnogo-upravleniya/

6. The impact of the COVID-19 pandemic on the activities of the Board of Directors (2020). Access mode: https://assets.ey.com/content/dam/ey-sites/ey$\mathrm{com} / \mathrm{ru} \mathrm{ru} /$ news/2020/08/ey-and-skolkovo-board-of-directors-survey-2020.pdf

7. The impact of the COVID-19 pandemic on the activities of the Board of Directors (2020). Access mode: https://www.ey.com/ru_ru/news/2020/08/ey-skolkovo-board-ofdirectors-survey

8. Most companies are planning to hire a director of digitalization in connection with the pandemic (2020). Access mode: https://realist.media/articles/insaydy/bolshinstvokompaniy-planiruyut-nanyat-direktora-po-tsifrovizatsii-v-svyazi-s-pandemiey/

9. Corporate governance, recommendations to the company's management regarding anticrisis response measures: Facing the COVID-19 pandemic (2020). Access mode: https://www.ifc.org/wps/wcm/connect/31cc77cc-7f6c-4063-b286-

2ec7e2c637b6/Tip+Sheet CG Company+Leadership COVID19 April2020 Russian. pdf?MOD=AJPERES\&CVID=n8fPlqt

10. COVID-19 CFOPulseCheck (2020). Access mode: https://www.bcg.com/ruru/publications/2020/covid-cfo-pulse-check-2 
11. A. M. Boin, M. Ekengren, M. Rhinard, Hiding in Plain Sight: Conceptualizing the Creeping Crisis, Risk hazards \& Crisis in public policy, 2, 116-138 (2020). Access mode: https://doi.org/10.1002/rhc3.12193 